\title{
Formula for Leadership
}

\begin{abstract}
This chapter presents Nika Gilauri's personal perspective on public leadership. He describes key success factors developed during his term as a leader in Georgia's reform government, initially as a cabinet member (from 2004, as minister of energy) and later as prime minister (2009-2012): a determined team, a shared vision, and decisive action. The chapter concludes with an account of crucial wartime leadership challenges during the Russian invasion of Georgia in 2008, including the story of how the author kept the country in cash with the help of a bottle of Jack Daniel's.
\end{abstract}

Keywords Leadership · Revolution · Team · Russia · war · George W. Bush

The transformation that took place in Georgia between 2004 and 2012 was more comprehensive, more substantial, and more sustainable than anyone would have hoped, especially in that part of the world. It is probably one of the finest examples of economic achievement in a small developing country in recent years, but the transformation went beyond economics. Despite many mistakes and setbacks, countries all over the world look to Georgia for inspiration because the results of lasting change for the better are clearly visible and widely recognized. The government that helped bring about this transformation relied on three principles: team, vision, and action. 


\subsection{TEAM}

Approach the government in some countries with a question, an issue, or a proposal, and nine out of ten times you will get the same answer, if you get an answer at all: "Sorry, not my remit." In Georgia's reform government, it was the exact opposite. No matter who - investors, entrepreneurs, citizens - came to any one of us, we made their concerns our own, regardless of whose department was formally responsible. We tackled every problem as a team, and every minister felt responsible for the government to succeed as a whole. Elsewhere, ministries are organizational silos, concerned only with their own performance. As a result, they often don't do anything, lest they be blamed when something goes wrong. And when something actually does go wrong, a minister's number one objective is typically to try and shift the blame to someone else. While our government wasn't entirely immune to this reflex, our creed was that we are one team, that we take decisions as a team, and that if anything goes wrong, we deal with it as a team. Internally, the constitutional bodies - the president, the prime minister, the cabinet, and the members of parliament - would argue a lot about every topic. But once a decision was made, we would all speak with one voice and do our best to see it through. There were two driving forces behind this attitude:

- Collective appointment. The cabinet was approved by the parliament as a whole, not minister by minister, as it is done in many other countries. In Georgia, it went as follows. The president was elected. Parliament was elected. The president presented a candidate for the prime minister to parliament, and the candidate presented a team and a program. Then parliament voted for, or against, the entire executive team and its program, not for or against individual ministers. This approach was adhered to even when there were changes in the cabinet. The prime minister could only replace up to 30 percent of the cabinet members, and four crucial ministries were exempt from the prime minister's discretion to begin with (interior, justice, defense, and penitentiary institutions). Once the admissible replacements were used up, the prime minister would have to seek a new mandate from parliament. Even the performance-based remuneration system was designed for the cabinet as a whole rather than for its individual members. Specifically, 50 percent of a minister's bonus was based on the 
performance of the country as a whole, as measured by the most comprehensive indicator, GDP growth.

- Common mindset. The members of the cabinet certainly disagreed and argued about a lot of political issues. Despite such disagreements, however, we shared a set of common values and attitudes. We were all in favor of democracy, meritocracy, and reform, inspired by and open to Western practices. We all felt that this was our one chance in life to do something for our country and make names for ourselves as men and women of action. Of course, it helped that we were all quite young when we were appointed. Nothing was sacred, and we were not afraid to try something new, or to fail. If we failed, we would try something else. There was a shared sense that innovation was a good thing, not a risk to be avoided.

Can other countries in need of reform replicate this spirit? I believe that they can. Many politicians complain that there is a lack of true talent in their countries, and that they have trouble attracting the best people to serve in the government or in state agencies. In my experience, the real problem is that politicians don't look beyond the usual suspects and hesitate to bring in new people. Of course, there is a limited number of good managers and daring innovators in any one party, or any one circle of people for that matter. The bold move that helped transform Georgia was to look for potential new team members all the time and everywhere. It does take guts, but it's not rocket science: find the most promising people, whoever they may be, and give them an opportunity to prove themselves. With this kind of approach, based on trial and error, you stand a much higher chance of creating a high-performing team than by thinking inside the box all the time. Of course, not every outsider will live up to the expectations, but over time, a new elite of civil servants will emerge. In Georgia, many heads of agencies and departments, and even many ministers and their deputies, were chosen not because of their affiliation with a party or a specific caste of people but because they had new ideas, felt strongly about particular topics, and were not afraid to speak their minds. In many cases, an appointment was made based on a simple conversation in which a candidate had impressed a cabinet member or an occasion on which a candidate had clearly excelled in the public eye. At one point, almost half the cabinet was not affiliated with any party. Even I, when serving as prime minister, was not a member of any party.

Another important characteristic of Georgia's reform government was its willingness to bring smart people into the team. Often, heads of 
organizations, agencies, ministries, or governments are afraid to appoint people they deem smarter than themselves as their subordinates, fearing that the new recruits will eventually challenge their authority or even make them redundant. The Georgian government that was in power from 2004 to 2012 had no such fear. Quite the opposite: ministers competed with one another to attract the smartest people to their staff, and they took pride in their teams. Cabinet members celebrated the accomplishments of their subordinates as if they were their own, an important source of motivation for junior staff members.

\subsection{VISION}

Few months after I took office as minister of energy in 2004, I asked my team to put together the calculations for a nationwide 24 -hour electricity supply. I will never forget the puzzled looks on their faces.

"Why bother?", they asked. "You know as well as we do that Georgia will not have 24-hour electricity supply in our lifetime."

This was coming from the top specialists in the field, people who had worked in the energy sector for much longer than I had, and who knew the Georgian electricity system much better than I did at the time. Within 18 months of this conversation, 24-hour power supply had become a reality, and in 2007, we were exporting electricity to our neighbors. This experience taught me to see opportunity where others see nothing but obstacles. I made it my mission to inspire others to think that anything is possible, and that a vision can become a reality if the best people pull together to make it happen.

In 2004, nobody could imagine that Georgia would one day become a regional tourist hub, let alone one of the world's top tourist destinations. When President Saakashvili first proposed an investment program to develop the tourism infrastructure in Batumi, a port on the coast of the Black Sea, almost everybody was skeptical. Nobody believed that such an effort could possibly amount to anything. Back then, Georgia was widely considered unsafe for foreign visitors, a fundamental issue for any budding travel destination. There were unresolved geopolitical problems in our relations with Russia. Some territories were (and still are) occupied by the Russian army. There was also no tourism infrastructure to speak of. We did not have a single five-star hotel, and getting to Georgia was difficult even for those who were determined to try. What is more, Georgia was 
facing fierce competition from top tourist destinations in the region, countries like Turkey and Greece. These countries have a well-established reputation among vacationers worldwide, world-class infrastructure, world-class connectivity, and milder climates affording longer tourism seasons. It took a grand vision, an enormous effort, and tremendous teamwork to make it happen, but it did happen. As early as 2011, Monocle magazine proclaimed a "Batumi Boom" and reported that "Georgia's second city is in the midst of a frantic transformation from sleepy resort to major tourist and investment hub."1 The number of visitors to Georgia increased from 350,000 in 2004 to five million in 2012 .

Had someone floated the idea of building a defense industry in Georgia in the mid-2000s, any expert in the field would have taken it for a joke and laughed out loud. At the time of writing, Georgia is not only producing equipment for its own defense systems but also exporting defense technology to other countries. ${ }^{2}$

The most important vision, however, was not tied to any sector or industry, be it energy, tourism, or defense. Rather, the big vision was that all stakeholders in the country - the population, investors, local businessmen, and civil servants - would rally around and work toward a common goal: building a better Georgia - a country that is free of corruption, has a highly efficient government, and acts as a hub in its region. A country in which poverty is a thing of the past and in which hard work will earn you a decent living. Mistakes were made along the way, and the transformation is not yet complete, but this is certainly not due to a lack of vision.

\subsection{ACTION}

The reform government was all about action and accountability. We took decisions as a team and saw them through as individuals who share the same set of values. The setup of the government and its procedures were specifically designed to support this approach. Even if some decisions were effectively made by individual ministers, the final and formal decision was mostly approved by the cabinet as a whole. There was a special committee for every major topic, comprising the relevant ministers, members of parliament, directors of state-owned companies and agencies, heads of relevant regulators, and experts in the field. Committee sessions were chaired by the prime minister. In-depth discussions about the development of a particular sector (be it energy, 
telecommunications, road infrastructure, or education) took place in these committees. Objectives and concrete steps to achieve these objectives were defined there, and the committees drafted decision proposals for the government. The cabinet convened every week and took decisions collectively by vote. The purpose of this collective voting was to make sure that every cabinet member was aware of what was going on and would back the outcome, no matter how complex the process leading up to the decision might have been. At the same time, one person, and one person only, was responsible for following up each decision and overseeing its implementation. Whenever two or more people were named as the responsible parties, conflicts or delays arose. This is why we combined collective decision making with individual responsibility for implementation. It helped us take bold decisions and ensure fast action.

Acting fast is also what helped Georgia cope with crises, and Georgia faced more crises over the course of a few years than some countries face throughout their entire history. Over time, crisis management became second nature to the government. Specifically, the team-based fast action approach helped Georgia survive various regional crises, such as the one in Ajara in $2004,{ }^{3}$ the energy crisis in $2006,{ }^{4}$ the world economic crisis that started in 2007 and hit Georgia in the midst of a home-grown political turmoil and an outflow of foreign capital; political crises, such as the blocking of the whole center of Tbilisi by the opposition in $2010 ;^{5}$ and the biggest crisis of all, the Russian invasion in August 2008.

\subsection{The Russian Invasion}

In August, 2008, Russian tanks started rolling into the Tskhinvali region. On August 12, 2008, the Security Council - most members of the government and some members of parliament - had gathered in President Mikheil Saakashvili's office. The Russian army was only about ten kilometers from Tbilisi and still advancing. None of us had slept in days. We were tired but full of energy and determination.

We were discussing the next steps. At the time, I was minister of finance and first deputy prime minister. All major roads, railroads, and points of entry had already been blocked. By cutting off all supplies, the Russians might try to get the Georgian population to rise up against their own elected government. 
"Okay, we need to decide on a few things," said Prime Minister Lado Gurgenidze.

"I will reach out to all the investors and all foreigners who have been doing any kind of business with Georgia," he announced. As a former banker, Lado was very good at "selling" the country, even in difficult moments like this one.

"The president, the minister of foreign affairs, and the Security Council are in talks with the international media and foreign politicians Americans, Europeans, and so on," he continued, "but we need somebody in charge of the economy, someone who will take care of the day-today economic affairs of the country, to make sure we get all the necessary supplies." There was silence.

"I propose that Eastern Georgia should be managed by Nika Gilauri," said the prime minister. Silence. Nobody agreed, nobody disagreed. I realized that I had a huge job to do, and that I should have left right away to get started. But I wanted to hear who my counterpart for Western Georgia would be, so that we would be able to coordinate our actions. I lingered for a few more minutes.

"Well, if there are no other candidates, then I guess Nika should be in charge of supplies for all of Georgia," Lado said and looked at me. What was there to say? I nodded, got up, explained that I had a lot to do, and said my goodbyes. It wasn't the first time that I was given a job nobody else wanted, simply because nobody could conceive how it was supposed to be done.

I rushed to my office. During the short drive, I thought about the tasks at hand. I would have to provide food, water, drugs, electricity, gas, petrol, and cash to a country invaded by 100,000 Russian soldiers and who knows how many tanks. There were Russian air strikes every day. The Russian army had taken control of most of the country's crucial infrastructure, including the port of Poti and the Georgian railway, and was moving toward Tbilisi. When I got to my office, I asked my team to gather all economic and social ministers right away. My office staff told me later that this was the first time I had a crazy look on my face. It was not surprising this was the first time I had no clue what to do.

I needed a plan. I needed a team. Instead, I found myself surrounded by a group of ministers who had no idea what to do either. They were all looking 
at me expectantly. This was when I realized that I couldn't let my own perplexity show. If they saw me acting lost, or as if I didn't know what I was doing, we would fail miserably. I mustered all my strength and convinced myself that I knew exactly what needed to be done. I started explaining my action plan. I could hardly believe my own words. A minute earlier, I had had no idea where even to start, let alone what my concrete action plan would be.

"Where danger threatens, salvation also grows," as Friedrich Hölderlin put it. ${ }^{6}$ Within one hour, we had an action plan. Initially, we focused on food. We had identified the twelve types of food that were most widely consumed: bread, cheese, butter, wheat, beef, poultry, milk, and so on. Monitoring this basket of essential products would alert us to imminent shortages. We tracked the prices of these products three times a day in Georgia's ten largest cities, including the capital and regional centers. In each city, we picked a handful of shops. We instructed three different government agencies to monitor the prices of each product type and send the information to my office. The representative of the local government was in charge of monitoring the prices in the morning, the department of statistics did the same thing in the afternoon, and the revenue service took over the evening shift. We had purposefully split the job between three agencies to ensure some measure of checks and balances. Everybody was nervous during these difficult days. Occasionally, local governors called us in a panic, claiming that their region was out of food and demanding that we send them additional supplies. Thanks to our triple sources, we knew that these claims were usually false. As soon as the price of one of the products in a particular region went up, we sent additional supplies of that product to the region. We didn't, however, give these supplies away for free but sold them to the local shops to make sure the regions received only what they really needed. This system helped us avoid any shortage of essential food products during the war.

Demand management was under control. Our next task was supply management. Where would we find the products we needed, and how would we get them to the regions? The Russian army had blocked both the railway and the main East-West highway. This is why we established two bases, one in Eastern Georgia and one in Western Georgia, each stocking the twelve essential food products. To stock the bases, we bought products from wholesalers, rather than from shops. This was to make sure there were no empty shelves in shops, which might have caused a panic among the population. In fact, we didn't even buy everything the wholesalers were 
offering. We left them with enough supplies to keep stocking shops in Tbilisi and in large cities.

I was relieved that our improvised system of price control was working. There was no shortage of any of the essential products and nobody panicked. Nobody even skipped a line in a supermarket, and nobody broke any traffic rules. The fact that the people of Georgia were so lawabiding, so supportive of each other, and so calm despite the invasion made me incredibly proud of my country. Still, that whole period is very much a blur to me. Our days started at $7 \mathrm{am}$ in the morning and ended at $4 \mathrm{am}$ the next morning. We went through prices, took stock of supplies, and arranged for deliveries. Based on our intelligence about the movements of the Russian army, we tried to anticipate where our citizens might take refuge and arranged to have food supplies waiting for them.

When food supplies started to run low at wholesalers' warehouses, we started importing food supplies ourselves. We rented a few warehouses around Tbilisi and near Batumi to store our imports. We bought supplies for Western Georgia from Turkey and for Eastern Georgia from Azerbaijan. As it happened, one of my fellow ministers, Alexander "Ale" Khetaguri, the minister of energy, had been on an official visit in Azerbaijan when the Russians invaded Georgia. I asked him to stay in Baku to help manage the imports. Every day, I received a report about the stock of supplies in our warehouses. Based on this information, we imported additional goods from Turkey and Azerbaijan.

There were even some cases of wartime heroism behind the lines. Quite understandably, some drivers had refused to drive trucks loaded with supplies through territory that was controlled by the Russians. In those cases, employees of the revenue service got behind the wheel themselves and drove the vehicles past the posts of the Russian army. In another case, we had to build a tent city to provide shelter for thousands of internally displaced persons from the Tskhinvali region. We had the necessary materials and we had a suitable site, but we had no manpower to put up the tents. Most members of the army and the police were at the front line. I called on the members of parliament to help out. In less than an hour, they were on site, with their friends and families, and rolled up their sleeves. By the next morning, the tent city was ready. It housed thousands of internally displaced persons - women and men, children and old people, newborn babies and pregnant women. Volunteers delivered bread and sausages several times a day to feed them. 
Thanks to determined leadership, good crisis management, and the tenacity of the Georgian people, Tbilisi did not fall in 2008. The population did not take to the streets to demand the resignation of the elected government, despite the Russians' best efforts to starve the capital and stir up an insurgence.

\subsection{Trading Jack For BenJAMIN}

In the midst of the invasion, I got a call from the National Bank.

"Nika, we are out of cash."

"What do you mean, you are out of cash? You are the National Bank. You have more than enough reserves."

"No, you don't understand. We have more than enough reserves, but these are all in accounts. What we don't have enough of is actual bills. The banks are running out of actual bank notes. Everybody is withdrawing US dollars and euros from ATMs. If we don't fill up the cash machines, they will run out in two days. We need to bring in cash from abroad."

"From where?"

"From Austria. We have already talked to them. Everything is ready. But how do we get the bills into Georgia?"

"How much are we talking about?"

"Around 350 million US dollars."

"Okay. I will take care of the logistics."

I tried to exude confidence, but in reality, I had no idea how to pull it off. Almost all flights to Georgia had been cancelled. Every plane entering Georgian airspace would be escorted by a Russian fighter jet. I pictured a cargo plane full of cash shot down by the Russians, showering us with Benjamins. ${ }^{7}$ Putting it all on a single plane was too big a risk. We would have to hedge our bets. I rang up the Georgia Air Company and asked them to send a plane to Vienna to pick up USD 100 million to cover the immediate need. I decided to have the rest flown to Azerbaijan and brought to Georgia by land, a much safer option. Ideally, we would 
have brought in the entire amount that way, but we needed the first USD 100 million the next day. Going through Azerbaijan would take much longer. To buy us some time, we announced an ad hoc bank holiday.

When the plane from Vienna finally landed at Tbilisi airport, I was there with an escort of eight special operations soldiers. I hadn't told anyone where we were going, or what we were transporting. Driving around a war zone with USD 100 million in cash is, well, a little risky to begin with, but telling people about it would have turned the operation into a downright suicide mission. As it happened, we delivered the package safely to the vault of the National Bank. I instructed the banks to re-open earlier than usual the next day to show everyone that there was no shortage of cash. The main concern was to avoid that lines of people would snake out of the banks. The banks managed it well. Some banks even gave cash to their employees and had them deposit it in their accounts for everyone to see, saying that they had withdrawn it that morning, that there was no issue with the supply, and that their money would be safer in their accounts than in their homes. By the end of that day, people started bringing back cash and depositing it in their accounts. The crisis was averted. Not one request by international depositor or investor was delayed for a minute.

I turned my attention to the remaining USD 250 million. I had the cash flown to Baku, Azerbaijan. Ale, Georgia's minister of energy, was still in Baku at the time. I called him on a secure line at the Georgian Embassy there and briefed him on the situation. I asked him to pick up the cash at Baku airport and bring it to the Azeri-Georgian border where I would meet him.

"Ale, listen carefully. When you leave the embassy, you will not have access to a secure line. So when you call me from your mobile, don't mention the money. Let's call it the guest. When you tell me that the guest has arrived, I will know that you have the cash. When you tell me that the guest is feeling well, I will know that you have counted the cash and it is all there. I may not be able to make it to the border in time because of the traffic. ${ }^{8}$ In that case, I will tell you to 'fuck off', and you will store the cash in a safe place in Baku. If, however, I tell you to 'get lost', you will bring the cash to the border. Understood?"

“Understood. But 'fuck off' and 'get lost' sound so similar. We might get confused. Can't we use a different code?" 
"I'm not feeling particularly creative right now, and there's no time. Let's stick with these phrases. Let's write down what they mean."

"Ok. I will call you in a few hours. But I have one request."

"What is it?"

At this point, I was prepared for pretty much anything, but Ale's answer still took me by surprise.

"You know how much I love Jack Daniel's."

"So?"

"I keep a bottle in my office. It was a gift from the US ambassador. When you come to the border, can you please bring me the bottle?"

"I'll tell you what. You bring me USD 250 million, and I will bring you the bottle. That's going to be the most expensive bottle of whiskey in the world."

We hung up. My phone rang a few hours later. I was on my way to the border. As I had feared it was almost impossible to get to the Azeri border.

"Nika, our guest has arrived."

"Is he feeling well?"

"Yes, he is ok. What shall we do?"

"Fuck off."

"Wait. Fuck off?"

I checked my notes.

"Yes, fuck off."

There was silence on the line. I realized that Ale, too, was looking at his notes.

"Ok. We will fuck off."

After a few hours, traffic had eased. I would finally be able to get to the border without further delays. Again, I could not tell anyone where I was going, or what my mission was. I was accompanied by the same team of special operations soldiers that had protected the pick-up at the airport. We were in two armored vehicles. To this day, there are allegations in 
Georgia that these vehicles carried members of the Georgian government trying to flee to Azerbaijan. But in fact, it was me on my way to trade a bottle of Jack for a truckload of Benjamins. I called Ale on his mobile.

"Ale, you can get lost now."

"What? Get lost? Wait, which one is that? So, get lost?"

"Yes, get lost."

“Okay."

A little later, I was in the neutral territory between the Georgian and Azeri borders, surrounded by handful special operations soldiers, holding a bottle of Jack Daniel's Tennessee Whiskey in my hand. It was pitch dark. I couldn't see a thing. I heard footsteps.

"Ale, is that you?"

"Who do you think?"

"Thank God."

Ale stepped into the light.

"Where is my whiskey?"

"I've got it right here."

I showed him the bottle and started moving toward him.

"Where is my money?"

"I've got it right here."

An armored truck inched forward into the light.

"Do you want to count it?"

"Have you counted it?"

"I have. It's all there."

“Okay. Here's your whiskey."

I passed him the bottle of Jack Daniel's. We said our goodbyes. I headed back to Tbilisi with USD 250 million in cash, and Ale headed back to Baku to help arrange for further food supplies to be brought into Georgia. 
A few days later, George W. Bush announced that the United States would send humanitarian aid to Georgia, and that he had charged the navy with delivering it ("Operation Assured Delivery"9). On September 8, 2008, the USS Mount Whitney, the flagship of the 6th U.S. Fleet, arrived in Georgia, carrying tons of aid and thousands of soldiers. The war was over.

\subsection{THE WAR RoOM}

A few days later, a high-ranking U.S. general asked me where I had received my wartime logistics training.

"It was an on-the-job training program. It started on August 8. I can't say that I like it, but I'm definitely learning a lot about crisis management."

The general smiled and asked whether he could see our war room.

"I was told that you are in charge of the war room, providing food supplies to the population. If it is not confidential, may I see it?"

"Of course," I said. I think he expected to see a sophisticated underground facility, with lots of computer screens and the latest communication technology. I took him to the war room - my office. A few tired-looking ministers were gathered there. One of them was taking a power nap on my couch. The strategic equipment consisted of a handful of mobile phones, a whiteboard filled with various calculations, and a large wall map of Georgia with markings that indicated the emplacements of the Russians and destinations for our food deliveries. For a second, the general looked at me with a frown, as if I was pulling his leg and hiding the true war room from him. But then he looked at our faces and realized that this was really it.

"May my assistant take a photo of the room?", he asked.

"Be my guest," I said.

I wonder whether that photo still exists.

\section{Notes}

1. https://monocle.com/magazine/issues/48/batumi-boom/(retrieved in May 2016).

2. http://georgiatoday.ge/news/3396/Georgian-Delta-to-Increase-Exportto-GEL-300-Million (retrieved in May 2016). 
3. http://www.crisisgroup.org/en/regions/europe/south-caucasus/geor gia/b034-saakashvilis-ajara-success-repeatable-elsewhere-in-georgia.aspx (retrieved in May 2016).

4. Russia blew up two gas pipelines leading into the country and a high-voltage electricity line simultaneously on the coldest winter day in 2006. See http:// news.bbc.co.uk/2/hi/europe/4637034.stm (retrieved in May 2016).

5. http://eng.kavkaz-uzel.ru/articles/13178/(retrieved in May 2016).

6. Patmos, by Friedrich Hölderlin (1803, first printed in 1807 in Musen almanach). English translation taken from Anselm Haverkamp, Leaves of Mourning: Hölderlin's Late Work, New York, SUNY Press, 1996, p. 48 (Haverkamp 1996).

7. "Benjamin" is a slang expression for the hundred dollar bill, referring to the portrait of Benjamin Franklin. See http://www.urbandictionary.com/ define.php?term=Benjamin\&defid=1384165 (retrieved in June 2016).

8. Many people were leaving the country, causing a traffic jam at the border between Georgia and Azerbaijan.

9. http://www.navy.mil/submit/display.asp?story_id=39560 (retrieved in May 2016).

Open Access This chapter is distributed under the terms of the Creative Commons Attribution 4.0 International License (http://creativecommons.org/licenses/by/4.0/), which permits use, duplication, adaptation, distribution and reproduction in any medium or format, as long as you give appropriate credit to the original author(s) and the source, provide a link to the Creative Commons license and indicate if changes were made.

The images or other third party material in this chapter are included in the work's Creative Commons license, unless indicated otherwise in the credit line; if such material is not included in the work's Creative Commons license and the respective action is not permitted by statutory regulation, users will need to obtain permission from the license holder to duplicate, adapt or reproduce the material.

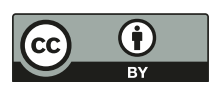

